\title{
ANALYSIS OF HEAT TRANSFER IN THE STRUCTURES WITH REGULARLY ARRANGED GAS CAVITIES
}

\author{
D. Cepīte, A. Jakovičs \\ Laboratory for Mathematical Modelling \\ of Environmental and Technological Processes, \\ University of Latvia, \\ 8 Zellıu Str, Rīga, LV-1002, LATVIA \\ e-mail: daiga.cepite@lu.lv
}

\begin{abstract}
In the work, the effective thermal conductivity (ETC) of anisotropic composite material (well-conducting media with regular cavities of the air) is studied by numerical modelling. The authors examine the influence of orientation and size of the cavities on the ETC of material structure and the role of thermal conduction, convection and radiation in the heat transfer processes. For modelling, Keraterm type material was chosen. It has been proved numerically that the ETC of similar structures is lower in the case when the cavities are oriented perpendicularly to the heat flux direction as compared with parallel orientation. According to the analysis performed, the radiation heat exchange in such cavities dominates over the convective heat transfer in the observed temperature range. In the calculations of ETC in structures of the kind, convection inside the cavities can be omitted. The proposed approach allows optimisation of the arrangement and size of the cavities in similar building materials. radiation.

Key words: effective thermal conductivity, heat conduction, convection and
\end{abstract}

\section{INTRODUCTION}

Inclusions of gases, due to their low thermal conductivity (e.g. $\lambda \approx 0.026 \mathrm{~W} / \mathrm{m} \cdot \mathrm{K}$ and $\approx 0.013 \mathrm{~W} / \mathrm{m} \cdot \mathrm{K}$ for air and argon used as insulators between glass panes of windows), play a significant role in fabrication of the building structures that should possess both high thermal insulation properties and high durability. The Keraterm material for building blocks (Fig. 1) is an example of the structures in which thermal conductivity is reduced by arranging air inclusions. The air volume fraction in such a block should not be increased too much to avoid the lack of mechanical strength, which is characteristic of highly porous structures. The most promising possibilities to minimize the effective thermal conductivity $\lambda_{\text {eff }}$ of the structure (in the case of a fixed air volume fraction) are seen in variations in the characteristic size and geometry of the cavities and their orientation towards the heat flux direction. Apart from the effective thermal conductivity $\lambda_{\text {eff }}$, each composite material can be characterised by thermal resistance $R=\Delta l / \lambda_{\text {eff }}$ and its inverse $U=1 / R$, but the best choice for comparing building structures with different thickness is to use $\lambda_{\text {eff }}$.

This is related to the thermal conduction and convection as well as to radiation heat transfer processes inside the cavities. Convective heat transfer caused by thermal expansion of gases (e.g. for air $\beta \approx 0.003 \mathrm{~K}^{-1}$ ) is a restrictive reason for 


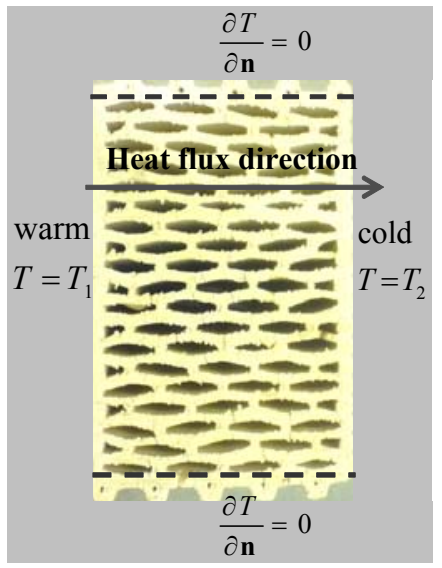

Fig. 1. Example of Keraterm building blocks (J/S Co. Lode). increasing the characteristic size of cavities or using vertical layers of air as insulator. It is well known that in the case of convection in-between two vertical glass panes the increase in the distance between panes beyond $18 \mathrm{~mm}$ does not lead to a decrease in the effective thermal conductivity. The mechanism of radiation heat losses due to surface emissive properties is also important. In real life situations, the intensity of convective heat transfer and radiation heat exchange is the highest in the winter time, when the difference between the indoor and outdoor temperatures is maximal. It is worth mentioning that humidity is another important factor which reduces the thermal resistance of the structure, however its influence has not been analysed in this work.

The aim of the present publication is to analyse the physical properties related to the heat insulation of a composite of the type which is formed of well conducting material with the thermal conductivity $\lambda>0.25 \mathrm{~W} / \mathrm{m} \cdot \mathrm{K}$ and regular airfilled cavities with elliptic cross-section. In particular, the heat transfer in the direction of the major and minor axes of the elliptic cavities is analysed.

In the case when cavities with lower thermal conductivity are included in the system the resulting heat flux is expected to decrease. To characterise the structure's effective thermal conductivity, Fourier's law can be rewritten as $Q=q S=$ $=-S \lambda_{\text {eff }} \Delta T / \Delta l$, where $Q(W)$ is the total heat flux through the side wall of surface area $S$. The effective thermal conductivity depends on the ratios $\lambda_{1} / \lambda_{2}$ and $\eta=V_{\mathrm{d}} / V$ (where $\lambda_{1}$ and $\lambda_{2}$ are the thermal conductivities of gaseous and solid domains, respectively, $V_{c}$ is the volume of gas in the structure, $V$ is its total volume), and on the geometry of the cavities and their orientation towards the heat flux direction as well as on the emissive properties of the cavity surface.

\section{MATHEMATICAL MODEL}

To model the impact of cavities on the effective thermal conductivity of a structure, the heat transfer equation includes the heat conduction, thermal radiation and convection terms. In the 2D case of conductive heat transfer through a moving opaque medium the temperature distribution is governed by the equation:

$$
\rho c_{p}\left(\frac{\partial T}{\partial t}+v_{x} \frac{\partial T}{\partial x}+v_{y} \frac{\partial T}{\partial y}\right)=\frac{\partial}{\partial x}\left(\lambda \frac{\partial T}{\partial x}\right)+\frac{\partial}{\partial y}\left(\lambda \frac{\partial T}{\partial y}\right),
$$

where $\rho$ is the density,

$c_{p}$ is the specific heat capacity, and $v$ the velocity of the medium.

In the case the considered element of media is solid and $v=0$, Eq. (1) transforms to the common Fourier's law [1].

The velocity $\boldsymbol{v}$ of the transient motion of incompressible gas in the cavity is determined by Navier-Stokes' equation in the Boussinesque approximation: 


$$
\left\{\begin{array}{l}
\frac{\partial \boldsymbol{v}}{\partial t}+(\mathbf{v} \nabla) \mathbf{v}=-\frac{1}{\rho_{l}} \nabla p+\nabla(v \nabla \mathbf{v})+\mathbf{f}-\mathbf{g} \\
\operatorname{div} \mathbf{v}=0,
\end{array}\right.
$$

where $p$ is the pressure,

$\rho_{l}$ is the density of the liquid/incompressible gas, $v$ is the kinematic viscosity,

$\mathbf{g}$ is the acceleration due to gravity,

$\beta=-\rho^{-1}(\partial \rho / \partial T)_{p}$ is the thermal expansion coefficient,

$\mathbf{f}=\beta\left(T-T_{0}\right) \mathbf{g}$ is the buoyancy force, and

$T_{0}$ is the reference temperature.

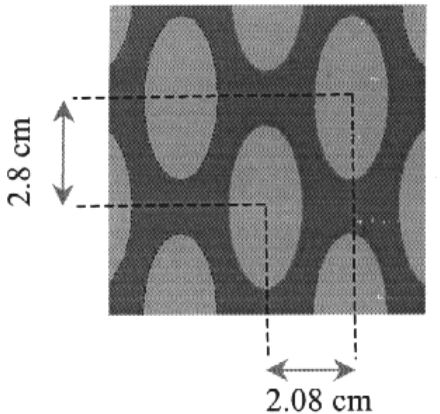

a)

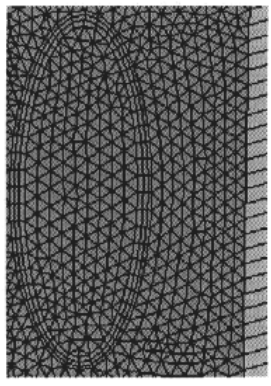

b)

Fig. 2. Sketch of the lattice of cavities (a); example of mesh for the mathematical problem (for the 2D model only a one-element deep mesh is used) (b).

In the present study, we seek a steady-state solution of Eqs. (1) and (2). The applicability of this model has been verified in work [2].

Since gas that fills the cavities is transparent, the discrete transfer (DT) model [3] was employed for the calculation of radiation heat exchange, assuming a diffuse reflection from the interfaces and grey radiation. The radiation heat exchange is determined by the equation:

$$
I(s)=\frac{\sigma_{S t B} T^{4}}{\pi}\left(1-e^{-a s}\right)+I_{0} e^{-a s},
$$

where $I \quad$ is the radiation intensity $I_{0}$;

$s \quad$ is the distance from the point with radiation intensity;

$T$ is the local temperature;

$\sigma_{S t B}=5.87 \cdot 10^{-8} \mathrm{~W} \cdot \mathrm{m}^{-2} \cdot \mathrm{K}^{-4}$ is Stefan-Boltzmann's constant.

The radiation heat flux density $q_{\text {rad }}$ between two parallel plates with temperatures $T_{1}$ and $T_{2}$ and the surface emissivities $\varepsilon_{1}$ and $\varepsilon_{2}$ are known to be related as

$$
q_{\text {rad }}=\sigma_{S t B}\left(T_{1}^{4}-T_{2}^{4}\right) /\left(1 / \varepsilon_{1}+1 / \varepsilon_{2}-1\right) \text {. }
$$

According to formula (4), the values $T_{1}=293 \mathrm{~K}, T_{2}=294 \mathrm{~K}$ and $\varepsilon_{1}=\varepsilon_{2}=0.9$ give $q_{\text {rad }} \approx 4.7 \mathrm{~W} / \mathrm{m}^{2}$. A typical magnitude of conductive heat transfer in building structures in winter time is in the range $5-20 \mathrm{~W} / \mathrm{m}^{2}$; consequently, for accurate 
calculations the radiation heat transfer should also be included. Formula (4) was used to verify the modelling of radiative heat exchange using DT model; a good agreement has been obtained.

The steady-state 2D problem was analysed in a rectangular domain (width $\Delta l$ and height $\Delta h$ ) with low-conducting air-filled elliptic cavities. Infinite depth of the domain was modelled by applying symmetry conditions to the front and back faces of the domain. Between two vertical side walls the temperature difference $\Delta T=$ $=T_{2}-T_{1}$ was assumed to exist (Fig. 1). The resulting heat fluxes were compared for different arrangements and geometries of the cavities.

Projections of the vector between the centres of two cavities were chosen 2.08 and $2.8 \mathrm{~cm}$, the semi-major axis of the cavity $-d_{1}=2.1 \mathrm{~cm}$, whereas the semiminor axis was varied in the range $d_{2} \in[0.37 \mathrm{~cm} ; 1.1 \mathrm{~cm}]$ to compare situations with different volume ratios $\eta=V_{\mathrm{c}} / V$ (here $V_{\mathrm{c}}$ is the volume of cavities in the rectangular domain, $V$ is its total volume). The thermal conductivity of the solid (e.g. a porous clay brick) was set to $\lambda_{2}=0.3 \mathrm{~W} / \mathrm{m} \cdot \mathrm{K}$, and the specific heat capacity - to $c_{p}=880 \mathrm{~J} / \mathrm{kg} \cdot \mathrm{K}$. Physical properties of the material filling the cavities were determined by the air parameters at $T \approx 310 \mathrm{~K}: \lambda_{1}=0.026 \mathrm{~W} / \mathrm{m} \cdot \mathrm{K}$, dynamic viscosity $\mu=1.92 \cdot 10^{-5} \mathrm{~Pa} \cdot \mathrm{s}$, thermal expansion $\beta=0.0043 \mathrm{~kg} / \mathrm{m}^{3} \cdot \mathrm{K}$, density $\rho(T)=2.4812-\beta T \mathrm{~kg} / \mathrm{m}^{3}$ and specific heat capacity $c_{p}=1004 \mathrm{~J} / \mathrm{kg} \cdot \mathrm{K}$. The absorption coefficient $a=0.01 \mathrm{~m}^{-1}$ and the emissivity of the gas-solid interface $\varepsilon=0.9$ were taken. Typical working temperatures were in the range $268 \mathrm{~K}<T<$ $<310 \mathrm{~K}$, which matches the real conditions for building structures.

To obtain the steady-state temperature and flow distributions, the ANSYS CFX software [3] was employed. An example of the mesh fragment is shown in Fig. $2 b$ (in total, (1-7) $10^{4}$ elements were used). The maximum residual below $5 \cdot 10^{-5}$ was used as the main criterion for convergence of the model. The total heat imbalance was monitored during the calculation process to be certain that the final solution corresponds to the steady-state condition.

\section{ANALYSIS OF THE RESULTS}

\section{1. One cavity case}

The first situation analysed is a structure formed of one elliptic inclusion with lower thermal conductivity $\left(\lambda_{2} / \lambda_{1} \approx 10\right)$, which is oriented perpendicularly to the heat flux direction (Fig. 3). In general, heat fluxes avoid the directions of lower thermal conductivity, therefore a contour curve around the inclusion and the highest temperature gradients appear inside the cavity. On both sides of the cavity, regions arise with the temperatures close to that fixed on the boundary (Fig. 3a). In the case when there is only conductive heat transfer, the effective thermal conductivity is lower for the cavity perpendicular to the heat flux $(0.17 \mathrm{~W} / \mathrm{m} \cdot \mathrm{K})$ than for that oriented parallel to it $\left(\lambda_{\text {eff }}=0.22 \mathrm{~W} / \mathrm{m} \cdot \mathrm{K}\right)$ by the same volume fraction $\eta=V_{\mathrm{c}} / V=0.22$ (Figs. $3 a$ and $4 a$ ).

In the case when the buoyancy and radiation heat transfer are included in the model, the effective thermal conductivity increases. The results show that at the average horizontal temperature gradient $\Delta T / \Delta l \approx 1.43 \mathrm{~K} / \mathrm{cm}$ the maximum velocity of convective motion is $1.6 \mathrm{~cm} / \mathrm{s}$ for the cavities oriented perpendicularly to the heat flux (Fig. $3 b$ ) and $1.1 \mathrm{~cm} / \mathrm{s}$ for those oriented parallel to it (Fig. $4 b$ ). The 


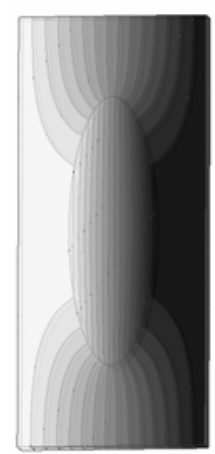

a) $0.17 \mathrm{~W} / \mathrm{m} \cdot \mathrm{K}$

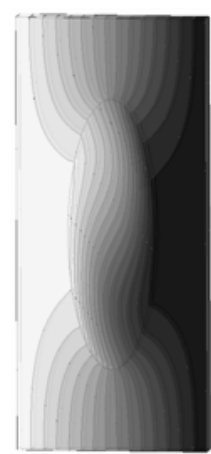

b) $0.18 \mathrm{~W} / \mathrm{m} \cdot \mathrm{K}$

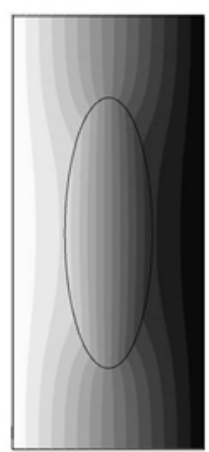

c) $0.22 \mathrm{~W} / \mathrm{m} \cdot \mathrm{K}$

Fig. 3. Distribution of temperature in a structure with one cavity oriented perpendicularly to the heat flux direction: a) non buoyant, b) buoyant, c) non-buoyant with radiation heat transfer. The direction of gravity force is downwards; lighter colour corresponds to higher temperature.

higher the velocity of convective air motion is, the larger the increase in the effective thermal conductivity. The convective velocity of the air $(v<2 \mathrm{~cm} / \mathrm{s})$ is low enough to assume laminar flow (typical Reynolds number is $\operatorname{Re}=v d_{l} / v \approx 50$ ). The numerical results show that the greatest increase in the $\lambda_{\text {eff }}$ (effective thermal conductivity) is achieved by the radiation heat exchange, since this mechanism is much more important than convection in these cases. The resultant effective thermal conductivity, due to conduction, convection and radiation, is lower in the case of cavity perpendicular to the heat flux than for that oriented in parallel to it: $\lambda_{\text {eff }}=0.22 \mathrm{~W} / \mathrm{m} \cdot \mathrm{K}$ and $\lambda_{\text {eff }}=0.26 \mathrm{~W} / \mathrm{m} \cdot \mathrm{K}$, respectively. It should be noted that, according to the numerical results, the calculation of convection inside the cavity for evaluating $\lambda_{\text {eff }}$ of the structure can be omitted. The effective thermal conductivities obtained with radiation and conduction differ from that obtained with conduction, convection and radiation only by 1 percent.

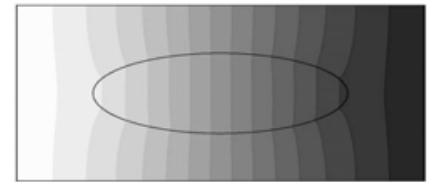

a) $0.22 \mathrm{~W} / \mathrm{m} \cdot \mathrm{K}$

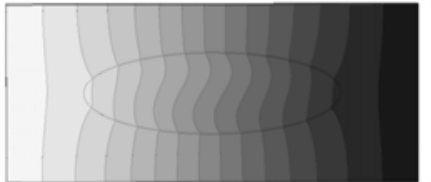

b) $0.23 \mathrm{~W} / \mathrm{m} \cdot \mathrm{K}$

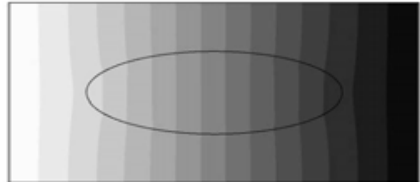

c) $0.26 \mathrm{~W} / \mathrm{m} \cdot \mathrm{K}$

Fig. 4. Temperature distribution in a structure with one low-conducting cavity parallel to the heat flux direction: $a$ ) non-buoyant, $b$ ) buoyant, $c$ ) non-buoyant with radiation heat transfer. The direction of gravity force is downwards; lighter colour corresponds to higher temperature.

\subsection{Conduction in the multi-layer model}

For practical purposes, understanding of the role of heat transfer mechanisms and its influence on the effective thermal conductivity in the structures with many regularly placed cavities is essential; also, of importance is the effect of cavity size and orientation on this parameter. To take all this into account, the models (see Figs. 5 and 6) with layered cavities have been created. The cavities in adjacent layers are arranged alternately, which reduces the effective thermal conductivity of the structure and improves its mechanical strength. 


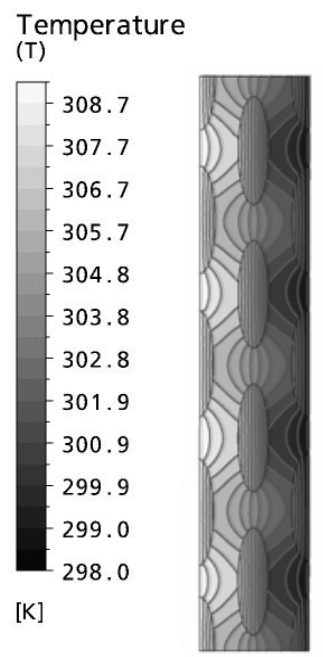

a) $0.12 \mathrm{~W} / \mathrm{m} \cdot \mathrm{K}$

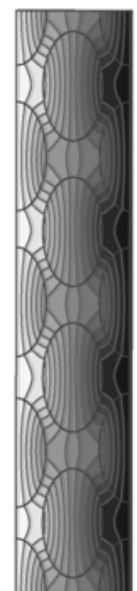

b) $0.07 \mathrm{~W} / \mathrm{m} \cdot \mathrm{K}$

Fig. 5. Temperature distribution in a structure with cavities oriented perpendicularly to the heat flux direction: $a) \eta=0.34, b) \eta=0.62$ (convection and radiation are ignored).

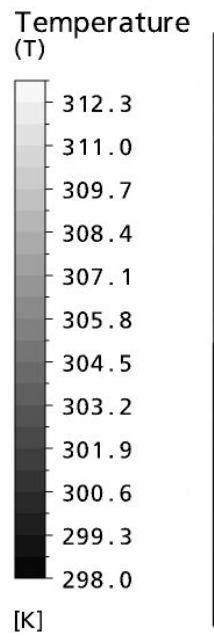

a) $0.20 \mathrm{~W} / \mathrm{m} \cdot \mathrm{K}$

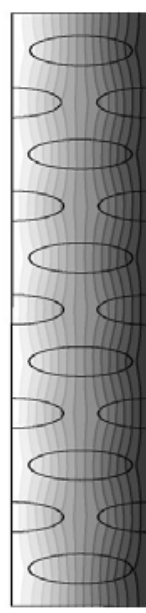

Fig. 6. Temperature

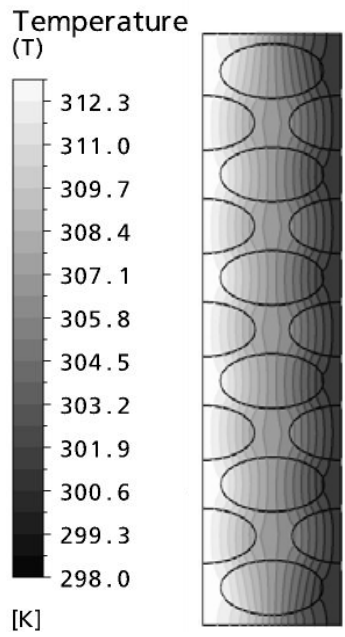

b) $0.11 \mathrm{~W} / \mathrm{m} \cdot \mathrm{K}$ in parallel to the heat flux direction:

a) $\eta=0.33, b) \eta=0.60$ (convection and radiation are ignored).

In the case of elliptic cavities with equal dimensions, it is impossible to increase the volume fraction of cavities $\eta$ too close to 1 to avoid a fall in the mechanical strength. Increase in $\eta$ leads to increase in the local temperature gradients in blocks, which could be a reason for cracking due to thermal tension.

In this model, dependence of $\lambda_{\text {eff }}$ on the geometry of cavities is analysed assuming conductive heat transfer only; this assumption makes it possible to estimate the maximum thermal resistance of the composite under consideration. Location of the centres of cavities has been maintained the same, whereas the semi-minor axis length was varied, which gives the range for $\eta$ between 0.2 and 0.62 . The chosen boundary conditions are shown in Fig. 1. Figures 5 and 6 display the converged 
steady state temperature distribution in the calculation domains with the cavity orientations perpendicular and parallel to the outer temperature gradient. According to the results obtained, the structure with perpendicularly placed cavities and $V_{\mathrm{c}} / V=0.34$ is almost as good insulator as the structure with $V_{\mathrm{c}} / V=0.6$ and the cavities placed in parallel (Figs. $5 a$ and $6 b$ ).

The effective thermal conductivities obtained in the model were compared with $\lambda_{\text {eff }}$ estimated analytically in two extreme situations - first, the cavities united in a layer parallel to the heat flux direction maintaining the characteristic cavity volume fraction in the structure, and second, the cavities united in a layer perpendicular to the heat flux direction. Calculation of $\lambda_{\text {eff }}$ in a two-layer structure is analogous to that for parallel or series connections of resistors (illustrated by Fig. 7). Figure 8 shows the dependence of effective thermal conductivity on the cavity volume ratio; the estimated dependence of $\lambda_{\text {eff }}$ on the air volume ratio in the basic two-layer model is depicted by a continuous line. In the figure it is seen that in the case of elliptic cavities the dependence of $\lambda_{\text {eff }}$ on the cavity orientation towards the outer temperature gradient is weaker. The results of numerical modelling with elliptic cavities lay in-between those for the two-layer model (in the case if only heat conduction is taken into account). The low thermal conductivity in the case of perpendicular layer orientation to the heat flux predicted by the analytical twolayer model is impossible in real life situations due to convection and radiation heat transfer that increase the effective thermal conductivity.

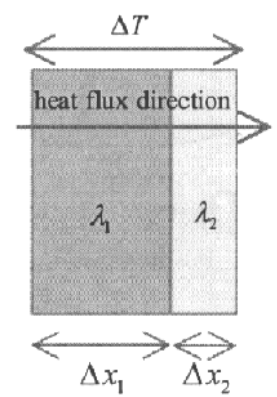

a) $\lambda_{\text {eff }}=\left(\Delta x_{1}+\Delta x_{2}\right) / R=\left(\Delta x_{1}+\Delta x_{2}\right) /\left(\Delta x_{1} \lambda_{1}+\Delta x_{2} \lambda_{2}\right)$

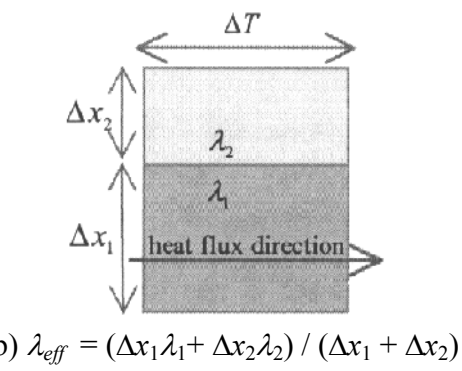

Fig. 7. Two-layer structures used to verify the model.

Layers are perpendicular $(a)$ and parallel $(b)$ to the heat flux direction.

$\lambda_{\text {eff }}$ is analogous to the total conductivity of parallel or series connected resistors.

To ascertain that the lack of cavities in the boundary zones of the structure and the small number of layers of cavities do not cause significant inaccuracy of $\lambda_{\text {eff }}$ 


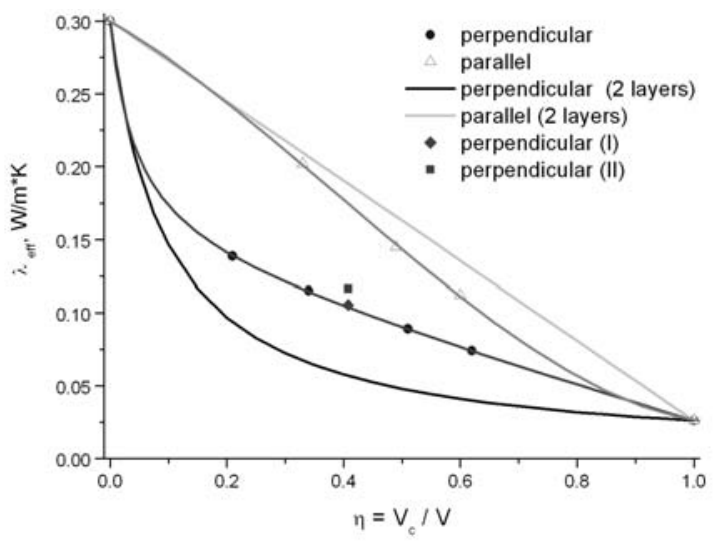

a)

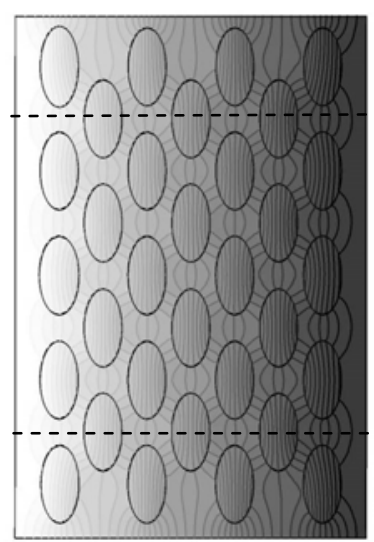

b) $0.12 \mathrm{~W} / \mathrm{m} \cdot \mathrm{K}$

Fig. 8. Dependence of effective thermal conductivity on the cavity volume ratio.

calculation, additional calculi in a larger domain (shown in Fig. 8b) have been done. The results of two methods for $\lambda_{\text {eff }}$ calculation (with $(I I)$ and without $(I)$ inclusion of the frontier layers above and below the dashed lines in Fig. $8 b$ ) are presented in Fig. $8 a$. It is seen that in the (I) case there is a good agreement with the results of the model shown in Fig. 5, which means that the effective thermal conductivity depends on the cavity geometry and orientation towards the heat flux direction and not on the numbers of cavity layers in the calculation domain. Since the heat flux in the outer zones is more intense (due to the lack of cavities with a lower thermal conductivity) the effective thermal conductivity (II) is slightly larger than (I).

\subsection{Convection and radiation heat transfer in a multi-layer structure}

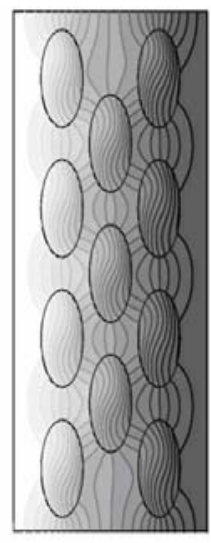

a) $0.13 \mathrm{~W} / \mathrm{m} \cdot \mathrm{K}$

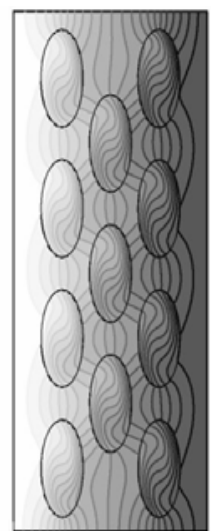

b) $0.14 \mathrm{~W} / \mathrm{m} \cdot \mathrm{K}$
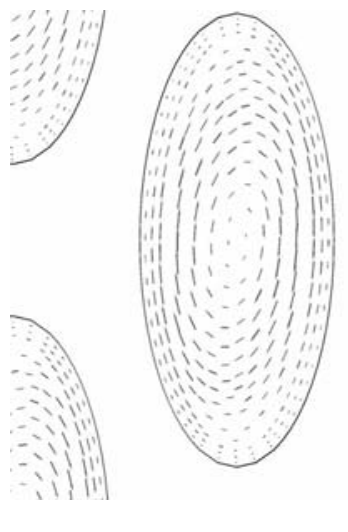

c)

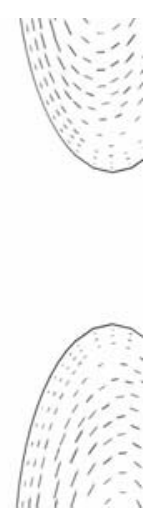

Fig. 9. Distributions of temperature:

a) $\Delta T=5 \mathrm{~K}, b) \Delta T=20 \mathrm{~K}$, and velocity: c) $\Delta T=5 \mathrm{~K}$.

Lighter colour corresponds to higher temperature; the direction of gravity force is downwards.

For calculation of the convective heat transfer, the model with fully incorporated cavities (Fig. 9) was used. 
Figure 10 shows that increase in $\Delta T$ (the temperature difference between two vertical boundaries spaced $8.3 \mathrm{~cm}$ apart) causes increase in the maximum velocity of convective flow and in the effective thermal conductivity of the structure. When $\Delta T$ is close to zero with the molecular mechanism of heat transfer only, $\lambda_{\text {eff }} \approx 0.126 \mathrm{~W} / \mathrm{m} \cdot \mathrm{K}$; in the case $\Delta T=20 \mathrm{~K}, \lambda_{\text {eff }} \approx 0.142 \mathrm{~W} / \mathrm{m} \cdot \mathrm{K}$; that is, although the effective thermal conductivity increases due to the convective heat transfer, the increase is insignificant.

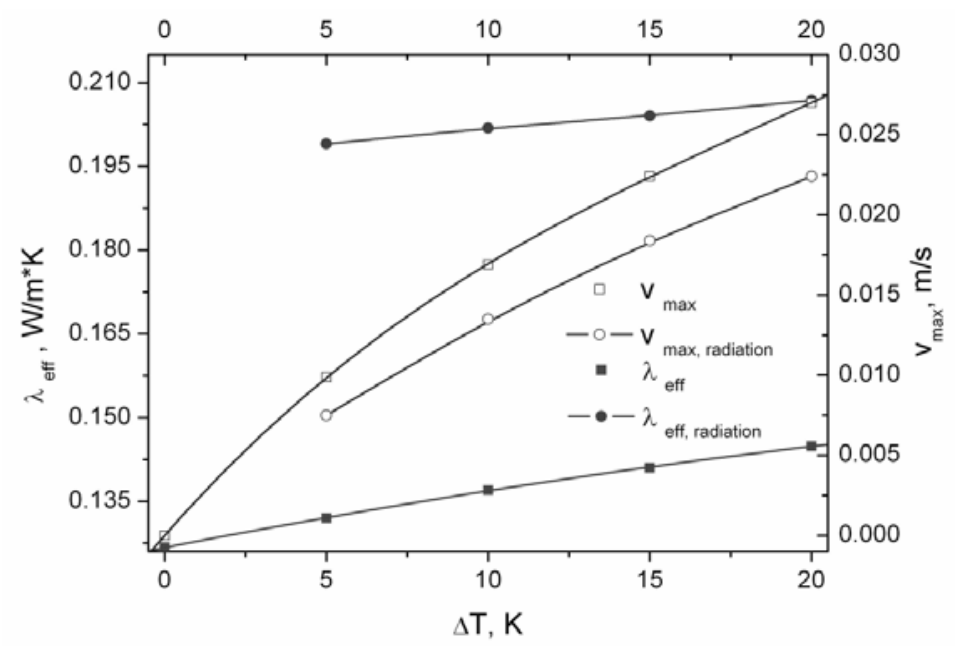

Fig. 10. Dependence of effective thermal conductivity and the maximum velocity of convective gas flow on the temperature difference $\Delta T$ between vertical boundaries with $\left(\lambda_{\text {eff, radiation }}, v_{\max \text {, radiation }}\right)$ and without $\left(\lambda_{\text {eff }}, v_{\max }\right)$ radiation heat transfer.

On the contrary, the radiation heat transfer significantly raises the effective thermal conductivity in the model shown in Fig. $11 b$. At $\Delta T=15 \mathrm{~K}$, with radiation heat transfer taken into account, the resultant value of this parameter is $\lambda_{\text {eff }} \approx$ $\approx 0.20 \mathrm{~W} / \mathrm{m} \cdot \mathrm{K}$; in the case when the radiation heat exchange is neglected, $\lambda_{\text {eff }} \approx$ $\approx 0.14 \mathrm{~W} / \mathrm{m} \cdot \mathrm{K}$ (Fig. 10). The temperature difference inside the cavity decreases due to the radiation heat transfer, which leads to a decrease in the intensity of convection characterised by the maximum velocity for a fixed $\Delta T$ (see Fig. 10).

So far, the impact of radiation heat transfer in the case of multiple elliptic cavities has been shown for the cavities oriented perpendicularly to the heat flux direction. In the case of their parallel orientation, the effective thermal conductivity of the structure due to conduction and radiation heat exchange is $0.25 \mathrm{~W} / \mathrm{m} \cdot \mathrm{K}$ (Fig. 11a). Nevertheless, the number of cavity layers is the same as in Fig. $11 b-$ the width of the structure is not equal in both the cases. The temperature difference between the opposite vertical sides of $6.7 \mathrm{~K}$ corresponds to the same ratio $\Delta T / \Delta l \approx$ $\approx 0.6 \mathrm{~K} / \mathrm{cm}$ as the difference of $5 \mathrm{~K}$ for the cavities oriented perpendicularly to the heat flux. At the differences in temperature on the opposite boundaries of the structure (shown in Fig. 11a) of $3.5 \mathrm{~K}, 6.7 \mathrm{~K}$ and $13.4 \mathrm{~K}$, the dependence of effective thermal conductivity on the temperature gradient is weak, being approximately $0.25 \mathrm{~W} / \mathrm{m} \cdot \mathrm{K}$ in all cases. The temperature difference is set by fixing the lowest temperature and varying the highest. The results show that the orientation of cavities parallel to the heat flux causes more heat losses through the structure than 
that perpendicular to it. It is shown that in the latter case the effective thermal conductivity can be reduced approx. by $20 \%$.

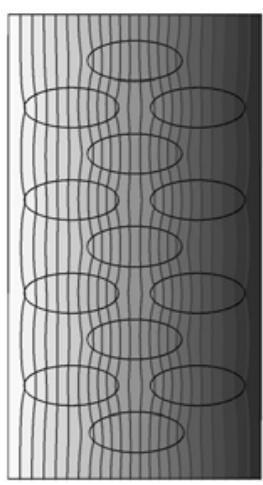

a) $0.25 \mathrm{~W} / \mathrm{m} \cdot \mathrm{K}$

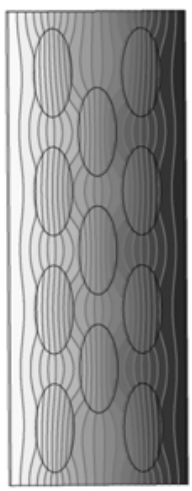

b) $0.20 \mathrm{~W} / \mathrm{m} \cdot \mathrm{K}$

Fig.11. Temperature distribution in a structure with cavities of lower thermal conductivity, oriented parallel $(a)$ and perpendicular $(b)$ to the heat flux direction.

\section{CONCLUSIONS}

Convection inside the cavities $(\eta=0.35$ and $\Delta T / \Delta l \approx 2.4 \mathrm{~K} / \mathrm{cm})$ is able to raise the effective thermal conductivity by $15 \%$. Under typical conditions, for the building blocks the temperature fall does not exceed $\Delta T / \Delta l \approx 1 \mathrm{~K} / \mathrm{cm}$, and in this situation increase in the effective thermal conductivity due to convection heat transfer is lower $(\approx 5 \%)$. On the contrary, the increase in $\lambda_{\text {eff }}$ due to radiation heat transfer is more significant: about $50 \%$ in the case $\Delta T / \Delta l \approx 1 \mathrm{~K} / \mathrm{cm}$. Therefore, to simplify the calculation process, the convective heat transfer could be ignored, whereas the radiation heat transfer should be included in the heat transfer calculation of similar building structures.

According to the numerical results, the structure with cavities oriented perpendicularly to the heat flux direction possesses lower effective thermal conductivity than that with cavities oriented in parallel to it. In the case of perpendicular orientation, the heat losses through the structure can be reduced by $20 \%$. To reduce the heat losses from buildings it is necessary to consider the perpendicular direction of cavities when developing the production of composite building materials.

The obtained range of effective thermal conductivity is in good agreement with that for Keraterm 44 building blocks produced by the $\mathrm{J} / \mathrm{S}$ Co. "Lode" $\left(\lambda_{\text {eff }}=0.13-0.23 \mathrm{~W} / \mathrm{m} \cdot \mathrm{K}[4]\right)$. Therefore the results obtained can be used to analyse different heat transfer mechanisms in building blocks with macroscopic cavities. This approach can be used effectively for optimisation of the cavity geometry by developing structures with the highest thermal resistance for a fixed volume fraction.

\section{ACKNOWLEDGMENT}

The work has been supported by the European Regional Development Fund $(E R D F)$. 


\title{
REFERENCES
}

1. Incropera, F.P., \& De Witt, D.P. (1990). Fundamentals of Heat and Mass Transfer. New York: John Wiley \& Sons.

2. Cepīte, D., Jakovičs, A., Halbedel, B., \& Krieger, U. (2008). Modelling of EM glass convection. Intern. J. for Computation and Mathematics in Electrical and Electronic Eng-g ( COMPEL), 27 (2), 387-398.

3. ANSYS CFX, Release 11.0 User's Guide.

4. Lodes būvniecības sistēma, 2. izd., A/S „Lode” (in Latvian).

\section{SILTUMA PĀRNESES ANALĪZE MATERIĀLA STRUKTŪRĀ AR REGULĀRI IZVIETOTIEM GĀZVEIDA DOBUMIEM}

\author{
D. Cepīte, A. Jakovičs \\ Kopsavilku m s
}

Pētījumā parādīts, kā, izmantojot lietišksās modelēšanas programmas, iespējams efektīvi prognozēt kompozītmateriāla ar anizotropām īpašībām efektīvo siltuma vadītspēju. Konkrēti tiek analizēta cieta materiāla ar eliptiskiem, ar gaisu pildītiem dobumiem siltuma vadītspējas atkarība no dobumu izmēra un orientācijas attiecībā pret siltuma plūsmu, kā arī termiskās konvekcijas un siltuma starojuma loma siltuma apmaiñas procesā.

Materiāla, kura parametri tuvi Keraterm blokiem un eliptisko dobumu garākā ass ir orientēta perpendikulāri siltuma plūsmai, efektīvā siltuma vadītspēja ir būtiski mazāka nekā struktūrai, kur dobumu garākās asis orientētas paralēli siltuma plūsmai pie tās pašas dobumu tilpuma dạ̦as materiālā. Analizētajā situācijā perpendikulāra izvietojuma gadījumā siltuma zudumi var tikt samazināti pat par $20 \%$, salīdzinot ar gadījumu, kad dobumi orientēti paralēli ārējā temperatūras gradienta virzienam.

25.06.2008. 